Arhe XVIII, 35/2021

UDK 37 Rousseau J.

DOI https://doi.org/10.19090/arhe.2021.35.313-333

Originalni naučni rad

Original Scientific Article

\author{
KRISTINA TODOROVIĆ \\ Univerzitet u Novom Sadu, Filozofski fakultet
}

\title{
SMISAO OBRAZOVANJA U RUSOOVIM DELIMA
}

Sažetak: Autor nastoji da ovim radom pokaže da se Rusoovo razumevanje obrazovanja u velikoj meri poklapa sa prosvetiteljskim idejama XVIII veka. Ruso se, zajedno sa ostalim enciklopedistima, zalagao za ideju emancipacije uma od autoriteta, i širenje znanja iz različitih oblasti nauka, filozofije, umetnosti, kao i znanja različitih zanata. Verovali su da će napredak u znanju doprineti i napretku društva. Međutim, Ruso se usudio da posumnja u ove ideje, zbog čega će biti nepravedno optužen da je od njih i odustao. Autor nastoji da u radu dokaže da je Rusoovo odstupanje od ovih ideja samo prividno, i da se njegova koncepcija prirodnog vaspitanja i obrazovanja uklapa u prosvetiteljske ideje. Kako bi dokazao ove tvrdnje, autor će koristiti metodu analize i komparacije Rusoovih tekstova sa tekstovima njegovih savremenika, kao i nekoliko relevantnih istraživanja autora koji se bave ovim i sličnim temama. Cilj ovog istraživanja je prikazivanje drugačijeg tumačenja Rusoovih ideja obrazovanja i vaspitanja, u odnosu na to kako su ih razumevali njegovi savremenici.

Ključne reči: Ruso, prosvetitelji, kritika, obrazovanje, prirodno obrazovanje

\section{UVOD}

Rusoovo (Jean-Jacques Rousseau) razumevanje obrazovanja je u velikoj meri određeno epohom u kojoj je živeo. Stoga, smatramo da je za valjano razumevanje Rusoove ideje obrazovanja, neophodno uzeti u obzir istorijsko-filozofski okvir Rusoovog delovanja. Shodno tome, izdvojićemo prosvetiteljske ideje XVIII veka kao ključne, a posebno projekat Enciklopedije, u kom je učestvovao i Ruso. U tom smislu, u radu ćemo se najpre osvrnuti na ove ideje i njihovu vezu sa obrazovanjem.

\footnotetext{
${ }^{1}$ E-mail adresa autorke: tina.todorovic@live.com
} 
Odabrali smo da u ovom radu analiziramo isključivo prosvetiteljske ideje, jer smatramo da su one u skladu sa Rusoovim koncepcijama obrazovanja. Naime, prosvetitelji su u razumevanje obrazovanja uveli određene novine, pa njihova misao, kao i Rusoova, predstavlja udar na tradicionalno razumevanje ovog pojma. Stoga, nastojaćemo da analizom i komparacijom Rusoovih dela, sa delima njegovih savremenika, ukažemo na ključna mesta gde se mogu uočiti poklapanja ovih ideja. Zbog toga, ovo istraživanje ćemo započeti upravo poglavljem Enciklopedisti $i$ značaj obrazovanja, kako bismo bliže pokazali pomenutu vezu prosvetiteljskih i Rusoovih ideja obrazovanja. Nastojimo da u ovom poglavlju pokažemo da su mislioci XVIII veka kritikovali ideju obrazovanja koja se odnosi na puko usvajanje znanja, bez potrebe da se preispita njihova istinitost $\mathrm{i}$ vrednost. Ovakva ideja obrazovanja, prema njihovom mišljenju, podrazumeva potpuno poverenje u autoritete, koje se kasnije prenosi i na čitavo društvo. Država i njene institucije, zajedno sa crkvom, predstavljaju najveće autoritete toga doba. Problem nastaje onda kada vladari i sveštenici počnu da zloupotrebljavaju svoj položaj i poverenje koje uživaju. Pokazaćemo da prosvetitelji vide rešenje ovog problema u emancipaciji ljudi od autoriteta bilo koje vrste.

Prosvetitelji su verovali da je moguće stvoriti društvo slobodnih pojedinaca, koji neće trpeti samovolju vladara i sveštenika. Smatrali su da je početak emancipacije od autoriteta upravo u odnosu prema znanju. Ideja je da ljudski um bude jedini autoritet kome treba verovati, zbog čega su insistirali na kritičkom promišljanju i želji za samostalnim posmatranjem i proučavanjem prirode. Pošto se vera u autoritete pokazala kao opasna, cilj je da čovek počne sve više da se oslanja na svoj sopstveni um. Kako bi što manje zavisili od drugih, i time izbegli rizik da budu iskorišćeni, ljudima se mora omogućiti prilika da stiču različita znanja iz različitih oblasti. Upravo za ovakvu ideju obrazovanja zalagali su se enciklopedisti, a sa njima i Ruso. Smatrali su da će paralelno sa napretkom nauka i umetnosti napredovati i društvo.

Drugo poglavlje u ovom istraživanju, Rusoov rad, sastoji se iz dva manja potpoglavlja: Rusoova kritika obrazovanja radi mode i Rusoov koncept prirodnog vaspitanja i obrazovanja. U ovom poglavlju, nastojaćemo da razjasnimo zbog čega su Rusoovi savremenici smatrali da se on udaljio 
od prvobitnih prosvetiteljskih ideja za koje se i sam zalagao. Cilj ovog poglavlja je da se pokaže da se Ruso, iako se zalagao za ovakve ideje, usudio da u njih i posumnja. Ako sopstveni um treba da bude jedini autoritet i sudija tome da li je neka ideja dobra ili ne, onda je dozvoljeno i neophodno sumnjati u sve ideje. Ruso se odvažio na to da do kraja promisli o tome da li šrenje obrazovanja (napredak nauka i umetnosti) zaista doprinosi boljitku i napretku društva. Međutim, Rusoa će zbog ove sumnje nepravedno optuživati da se udaljio od prosvetiteljskih ideja. Naša teza je da je Ruso ipak ostao dosledan prosvetiteljskoj ideji obrazovanja, a da je udaljavanje od te ideje samo prividno. Smatramo da se Ruso zalagao za emancipaciju od autoriteta, ali i za emancipaciju od loših načina i metoda koje su se tada praktikovale u obrazovanju dece. Tumačićemo Rusoov rad kao pokušaj da se zamisao o širenju obrazovanja sprovede u delo, ali na onaj način koji će doprineti tome da se prosvetiteljske ideje o slobodnim pojedincima, sposobnim da samostalno misle, zaista i ostvare. Pokušaćemo da dokažemo ovu tezu razmatranjem dva aspekta Rusoovog rada. Prvi se odnosi na njegovu kritiku društva i dotadašnjeg razumevanja obrazovanja, koji ćemo razmatrati u potpoglavlju Rusoova kritika obrazovanja radi mode. U ovom potpoglavlju pokazaćemo da je Ruso smatrao da tadašnje društvo nije bilo spremno da istinski razume prosvetiteljske ciljeve, jer je obrazovanje doživljavalo kao još jedan modni talas. Ruso kritikuje tadašnji obrazovni sistem koji jednostavno nije bio podoban za sprovođenje pomenutih ideja. Ukazivao je na to da je društvo postalo previše licemerno i izveštačeno, samim tim i nespremno da se odrekne svojih loših navika u korist bilo kakvog napretka.

Drugi aspekt Rusoovog rada, razmatraćemo u potpoglavlju Rusov koncept prirodnog vaspitanja $i$ obrazovanja. U ovom potpoglavlju govorićemo o Rusoovom predlogu novog načina obrazovanja i vaspitanja koji je nazvao prirodnim obrazovanjem. Ideja je da pokažemo da Ruso nikada nije odustajao od prosvetiteljskih ciljeva. Da bi se prosvetiteljske ideje zaista mogle ostvariti, smatrao je da je najpre potrebno vaspitati i obrazovati decu izvan okvira izveštačenog i izopačenog društva. Jedino tako će ona biti spremna da se u to društvo vrate kao samostalni i sposobni pojedinci. Videćemo da je Ruso insistirao na tome da dete od početka razvija svoju radoznalost i želju da shvata svet oko sebe. Da bi se to postiglo, 
neophodno je imati odgovarajuće učitelje, spremne da na pravi način usmeravaju svoje učenike, učeći ih pravim vrednostima i time se boriti protiv licemerja društva.

U zaključku ćemo sumirati osnovne ideje rada, i još jednom pokazati da Rusoova namera nije bila da odstupi od prosvetiteljskih ideja, već da ih valjano sprovede u delo. Njegov projekat prirodnog vaspitanja i obrazovanja nosi u sebi nadu da je promena u društvu ipak moguća, i da se do te promene dolazi jedino ispravnim načinom vaspitanja i obrazovanja dece. Ruso nikada nije bio protivnik nauka i umetnosti, već se zalagao za emancipaciju od loših metoda kojim se ta znanja prenose na decu. Cilj ovog istraživanja jeste ukazivanje na drugačiju perspektivu analize Rusoovog rada i njegovog odnosa sa prosvetiteljskim idejama, od one koju su zastupali njegovi savremenici.

\section{ENCIKLOPEDISTI I ZNAČAJ OBRAZOVANJA}

Pre nego što počnemo sa analizom Rusoovog razumevanja pojma obrazovanja, osvrnućemo se najpre na rad njegovih kolega i savremenika. Smatramo da će nam ovaj kratak osvrt na epohu u kojoj je Ruso živeo biti od velike koristi, kako bismo mogli bolje da razumemo značaj koji se tada pridavao obrazovanju i način na koji se ono tada tipično razumevalo, a samim tim i da možemo bolje oceniti položaj Rusoove filozofije obrazovanja $\mathrm{u}$ datom kontekstu.

XVIII vek poznatiji je kao vek prosvetiteljstva, koje se, sa jedne strane, može tumačiti kao pokret koji je: ,,...razornički usmeren protiv onoga što pozitivno postoji: protiv religije, protiv navika, običaja, mnenja, protiv svetskog stanja u pogledu zakonskog poretka, protiv državnih ustanova, pravosuđa, načina vladavine, protiv političkog i juridističkog autoriteta, protiv državnog ustava i tako protiv umetnosti.“2 Činjenica je da su prosvetitelji bili veoma kritički nastrojeni prema državnim institucijama, kao i prema crkvi, ali to ne znači da su se borili protiv ideja države i religije kao takvih, već protiv zloupotrebe ljudi koju su sprovodili vladari i sveštenici.

\footnotetext{
${ }^{2}$ Hegel, Georg Vilhelm Fridrih, Istorija filozofije III, BIGZ, Beograd, 1975, str. 398.
} 
Kako Hegel (Georg Wilhelm Friedrich Hegel) navodi, smisao religije i crkve se u ovom dobu izgubio, zbog čega su usledili napadi prosvetitelja na: „najsramnije praznoverje, popovštinu, glupost, izopačenost naravi, a pre svega proćerdavanje bogatstva i nasleđivanje u ovozemaljskim dobrima, pored opšte bede.“3 Isto važi i za državu, koja se pretvorila u: „,najbezumniju vladavinu ministara i njihovih ljubavnica, žena, dvorjanina; tako da je ogromna vojska sitnih tiranina i besposličara smatrala za svoje božansko pravo da pljačka državne prihode stečene znojem naroda. ${ }^{\text {"4 }}$ Oni koji su bili na čelu države i crkve koristili su moć nad običnim ljudima kako bi ostvarivali svoje lične interese. Posledica toga bila je sve veće nezadovoljstvo intelektualaca tog doba, a koje mi nazivamo prosvetiteljima. Rad prosvetitelja je bio usmeren na kritiku ovakvih pojava u društvu, ali i na pronalaženje adekvatnih rešenja ovog problema.

Smatralo se da su moćnici toga doba koristili upravo neznanje kao oružje manipulacije. Rešenje u koje su tadašnji mislioci verovali bila je ideja obrazovanja što većeg broja ljudi: ,...ljudi ne treba više da budu laici, i to ni u pogledu religije ni u pogledu prava“"5. Reč je o tome da se izgubi privilegija ,,izuzetnih“ pojedinaca koji jedini imaju pravo na znanja iz oblasti religije i prava, kao i svih ostalih civilizacijskih dostignuća, kao što su nauke i umetnosti: ,...tako da u religijskom životu ne postoji neka hijerarhija, neki zatvoreni krug izabranih sveštenika, isto tako ni u pravnom životu ne postoji neka isključiva kasta i društvo (čak ni neki pravični stalež) u kojima se jedino zna šta je večno, božansko, istinito i pravedno... već da ljudski um ima pravo da se sa tim saglasi i da na to pristane. “6 Suština je u tome da svako ko istinski želi da proširi svoje znanje o nečemu ima mogućnost da to i učini.

Dakle, XVIII vek, pored pomenutih kritičkih stavova, donosi i neku vrstu optimizma. Prosvetitelji su smatrali da je njihovo doba zapravo vreme kada se ostvaruje novovekovna zamisao o emancipaciji uma od svih ostalih

\footnotetext{
${ }^{3}$ Isto, str. 399.

${ }^{4}$ Isto.

${ }^{5}$ Isto.

${ }^{6}$ Isto, str. 399, 400.
} 
autoriteta, i da je vlastiti um jedino čemu se može verovati. ${ }^{7}$ Kao što smo u prethodnom pasusu videli, da bi se to ostvarilo, neophodno je da ljudi više ne budu laici, odnosno da im znanje o različitim stvarima bude nedostupno. Samim tim, pitanje obrazovanja je postalo veoma značajno pitanje kako za Rusoa, tako i za njegove savremenike.

Prosvetitelji su smislili način kako da svoju ideju o širenju obrazovanja sprovedu u delo, zbog čega su otpočeli sa radom na projektu Enciklopedije. Ruso je takođe radio na ovom projektu, koji su započeli Deni Didro (Denis Diderot) i D'Alamber (Jean le Rond D'Alambert). Cilj ovog projekta bio je da se napiše rečnik nauka, umetnosti i zanata, koji predstavlja pokušaj sabiranja svih korisnih znanja i postignuća ljudske civilizacije. Naravno, D'Alamber i Didro su bili svesni toga da je ovakav projekat veoma komplikovan, zbog čega je neophodno angažovanje brojnih stručnjaka iz različitih oblasti ${ }^{8}$, među kojima je bio i Žan Žak Ruso.

Pošto je um jedino na šta se treba oslanjati, čovek je dobio tu mogućnost da sumnja i preispituje sva znanja, kao i da sam odlučuje i prosuđuje o tome koja će od njih prihvatiti, a koja odbaciti. Kako Rasel (Bertrand Russell) primećuje, protestanti su imali ideju da svako treba samostalno da prosuđuje o Bogu - bez ikakvih posrednika, i upravo ova ideja se kasnije primenila i na istraživanje i saznanje prirode. Novina tog doba bila je mogućnost da svako ko se razume i zanima za nauku može imati uvid u istraživanja naučnika. Naučnici su se trudili da rezultati njihovog rada budu dostupni i drugima. Um je sada preuzimao ulogu autoriteta, zbog čega se ,odbacuju" oni autoriteti kojima se nekada slepo verovalo. ${ }^{9}$

Kada je reč o „odbacivanju", ne misli se na zanemarivanje svega onoga što je tradicija stvorila, već je reč o novoj mogućnosti, mogućnosti preispitivanja onoga što se do tada držalo kao nesumnjivo i neupitno. Kao što nam D'Alamber kazuje, problem je nastao onda kada se promenio način na koji ljudi doživljavaju obrazovanje, ili, kako on kaže, „učenost“ ${ }^{10}$ Prema

\footnotetext{
${ }^{7}$ Krstić, Predrag, Kritički pojmovnik civilnog društva I, Grupa 484, Beograd, 2003, str. 183, 184.

${ }^{8}$ Dalamber, Žan le Ron, Uvodna rasprava u Enciklopediju, Kultura, Beograd, 1955, str. 3.

${ }^{9}$ Russel, Bertrand, Mudrost zapada, Mladost, Zagreb, 1959, str. 232.

${ }^{10}$ Dalamber, Žan le Ron, Uvodna rasprava u Enciklopediju, str. 37.
} 
njegovom sudu, ljudi su samo puko usvajali dostignuća svojih predaka, a njihov pravi smisao i vrednost se polako gubila iz vida. D'Alamber navodi da je otkriće štamparije omogućilo ljudima da im dela starih pisaca budu lako dostupna, što je doprinelo tome da čitanje i proučavanje tuđeg rada bude popularnije od samostalnog istraživanja: ,...mislilo se da je dovoljno da se ova dela čitaju pa da se postane učen, i odista je lakše čitati nego videti. Tako će ljudi gutati bez razlike sve ono što su stari ostavili u svim oblastima: prevodili su ih, komentarisali i, iz neke vrste zahvalnosti, počeli da ih obožavaju, a da skoro nisu ni znali njihovu pravu vrednost.“"11 Dakle, nije dovoljno samo slepo verovati i obožavati spise naših predaka, već je potrebno da se i sami upustimo u proučavanje prirode. Gomilanje znanja bez kritičkog rasuđivanja ne doprinosi boljitku i napretku čovečanstva, već nosi sa sobom opasnost da se ponovo padne u mrežu manipulacija moćnika. Zbog toga se ne sme dozvoliti nikakav drugi autoritet; ništa više osim našeg uma ne može biti garant tome da su ta znanja ispravna i istinita.

D'Alamber navodi da je za ovaj novi način filozofskog mišljenja zaslužan Dekart (Rene Descartes). ${ }^{12}$ Dekart je predstavnik one novovekovne vere u emancipaciju uma od autoriteta koju smo prethodno već pomenuli. On se zalagao za ideju ponovnog preispitivanja svih znanja koja posedujemo. Čak i kada nije siguran u svoje znanje, čovek će uvek težiti tome da dođe do nekakvih objašnjenja: „Nepouzdanost i taština duha su takvi da on uvek oseća potrebu za jednim mišljenjem za koje se vezuje: to je dete kome treba pružiti igračku da bi mu se otelo opasno oružje, a ono će samo napustiti ovu igračku kada bude dospelo u zrelo doba. “13 D'Alamber je smatrao da u takvoj situaciji čovek ipak može biti svestan svog položaja. On je poput deteta koje je trenutno zadovoljno svojom igračkom, ali koju je takođe spremno da odbaci kada stupi u zrelo doba. Upravo je to ideja koju je D'Alamber prepoznao kod Dekarta, i u nastavku kaže: „Stvarajući na taj način promene mišljenja, filozof ili oni koji misle da su filozofi, uče se bar da sumnjaju u svoja objašnjenja, i ovo raspoloženje duha je prvi korak ka

\footnotetext{
${ }^{11}$ Isto.

12 Isto, str. 47, 48.

${ }^{13}$ Isto, str. 48.
} 
istini."14 Zagovarajući sumnju i mogućnost preispitivanja svih stavova, enciklopedisti su predstavljali pretnju onima koji su koristili neznanje ljudi u svrhu ostvarivanja ličnih interesa. Kako Volter (Voltaire) navodi, Enciklopediju su okarakterisali kao: ,...zbornik bezbožnosti i huljenja koji na svakoj strani odiše pobunom protiv religije i autoriteta. " ${ }^{15}$ Volter je takođe bio žestok kritičar tadašnjeg crkvenog autoriteta i svešteničke zloupotrebe položaja; kako šaljivo kaže: ,...vi biste htjeli da imate kao i oni povlasticu da slobodno ispitujete, da mislite svojom glavom, da sveštenicima oduzmete drevno pravo da misle za vas i da upravljaju vama." ${ }^{\text {"16 }}$

Enciklopedisti su imali san o čoveku sposobnom da samostalno misli, pa je zbog toga Enciklopedija zamišljena kao delo koje ce uputiti i motivisati ljude da stiču što više znanja, kako bi mogli što slobodnije i ispravnije da rasuđuju. Verovali su u to da će Enciklopedija: „,...bar jednoga dana, zameniti građaninu biblioteku u svim oblastima, a profesionalnom naučniku u svim oblastima izuzev one koju on proučava, da će ono razviti istinske principe stvari, da će utvrditi njihove odnose, da će doprineti izvesnosti i napretku ljudskih saznanja i da će, uvećavati broj istinskih naučnika, istinskih umetnika i posvećenih amatera, doneti društvu nove koristi.“17 Vidimo iz prethodnog citata da je D'Alamber, poput ostalih enciklopedista, verovao u ideju da će sa rastom znanja doći i do napretka društva. Enciklopedisti su smatrali da su njihovi preci očigledno grešili jer su dozvolili da se društvo razvija u potpuno pogrešnom smeru, a uslovi života postanu sve gori. Međutim, oni su takođe smatrali da se takvo stanje može izmeniti, a da buduća pokolenja imaju mogućnost za bolju budućnost. Verovali su u ideju da će napredak u saznanju doprineti stvaranju boljeg društva. ${ }^{18}$

Ipak, iako su pravili mnogo grešaka, naši preci su takođe stvorili mnogo toga dobrog i lepog što bi generacijama koje dolaze moglo biti od koristi. Zato je cilj enciklopedista da sve to pribeleže i sačuvaju na jednom

\footnotetext{
${ }^{14}$ Isto, str. 48.

15 Volter, „Hrišćanski razgovor ili obezbjeđivanje od Enciklopedije“, u: $U$ ime savjesti i razuma, Svjetlost, Sarajevo, 1960, str. 201.

${ }^{16}$ Isto, str. 203.

${ }^{17}$ Dalamber, Žan le Ron, Uvodna rasprava u Enciklopediju, str. 75.

${ }^{18}$ Krstić, Predrag, Kritički pojmovnik civilnog društva I, str. 188.
} 
mestu: „Koliko bi koristi imali naši očevi i mi sami da su radovi starih naroda, Egipćana, Haldejaca, Grka, Rimljana itd., bili sačuvani u jednom enciklopedijskom delu, u kom bi istovremeno bili izloženi pravi principi njihovog jezika! Učinimo, dakle, za vekove koji će doći ono što žalimo što prošli vekovi nisu učinili za naš!"19 Kao što smo napomenuli, ideja je da se najpre osveste greške koje su ljudi pravili u prošlosti kako bi se sprečilo njihovo ponavljanje, a to su slepo verovanje autoritetima i puko usvajanje znanja bez preispitivanja njihovog značaja i vrednosti. Zamisao je da novi vaspitači vaspitaju nove generacije, koje će razvijati svoju sposobnost samostalnog mišljenja, i time stvoriti bolje i slobodnije društvo.

\section{RUSOOV RAD}

Videli smo u prethodnom poglavlju da je Ruso učestvovao u pisanju Enciklopedije, čiji smo smisao pokušali da iznesemo u vrlo kratkim crtama. Međutim, Ruso je dospeo u centar pažnje javnosti tek kada je pobedio na konkursu koji je raspisala Akademija u Dižonu. Učesnici konkursa su imali zadatak da odgovore na pitanje da li obnova nauka i umetnosti doprinosi popravljanju morala. Suprotno očekivanjima, Ruso je napisao tekst u kome obrazlaže svoj negativni odgovor. Vera u napredak čovečanstva koji ide uporedo sa razvojem nauka i umetnosti dovedena je u pitanje. S obzirom na to da smo prethodno izneli potpuno drugačije stavove enciklopedista koji se tiču veze obrazovanja i napretka, postavlja se pitanje da li se Ruso sa svojim stavovima upleo u mrežu kontradiktornosti? U istraživanju koje sledi, pokušaćemo da pokažemo da ipak nije reč o kontradiktornim stavovima, već da je Ruso nameravao da nam kaže nešto više o društvu u kom je živeo, kao i o odnosu koje to društvo imalo spram obrazovanja.

Smatramo da je Ruso, uprkos tome što je i sam učestvovao u pisanju Enciklopedije i širenju svesti o značaju obrazovanja, osetio potrebu da preispita koliko je društvo zapravo spremno da razume smisao ovih ideja. Prema rečima Kenet Vejn (Kenet Wain), Didro je znao za spis nazvan Rasprava o naukama i umetnostima i ohrabrivao je Rusoa da ga pošalje na konkurs. Didro je čak razmišljao i o objavi ovog spisa u okviru

${ }^{19}$ Dalamber, Žan le Ron, Uvodna rasprava u Enciklopediju, str. 71. 
Enciklopedije, što Kenet Vejn smatra veoma „,neobičnim“. ${ }^{20}$ Zaista, sa jedne strane imamo borbu enciklopedista za ideju da ce napredak nauka i umetnosti doprineti poboljšanju ljudskog društva, dok sa druge strane imamo Rusoovu tezu da je upravo to razlog zbog kog se društvo izopačilo. Postavlja se pitanje zašto bi se Didro, kao jedan od inicijatora projekta Enciklopedije, oduševio ovom Rusoovom idejom?

Podsetimo na to da su enciklopedisti najpre pozivali na kritiku i preispitivanje svih mogućih ideja, uključujući i one sopstvene, što je dovoljan razlog da se posumnja i u ideju napretka društva koji dolazi zajedno sa razvojem znanja, a to je upravo ono što je Ruso uradio. Nije nepoznato da je među enciklopedistima postojala bojazan da se njihove ideje neće shvatiti na pravi način. Tako D'Alamber u „Uvodnoj raspravi u Enciklopediju“, poredeći različite odnose koje Engleska i Francuska imaju prema radu naučnika, kaže: „Ljubav za znanjem, koja predstavlja vrednost kod naših suseda, kod nas je u stvari još samo jedna moda i možda nikada neće biti drukčije. “21 Da li je potreba za obrazovanjem shvaćena kao ozbiljno pitanje od koga zavisi budućnost čovečanstva, ili je ona shvaćena kao prolazni talas koji diktira ,,moda“, predstavlja presudno pitanje za Žan-Žaka Rusoa.

D'Alamber nam u nastavku pomenutog dela otkriva da je upoznat sa Rusoovom idejom, te kaže: „Ne bi nam priličilo da budemo njegovog mišljenja na početku dela kao što je ovo, a ovaj čovek od vrednosti izgleda da se složio sa našim radom sudeći po marljivosti i uspehu sa kojim je u njemu učestvovao. Mi mu nikako nećemo prebacivati što je pomešao duhovnu kulturu sa zloupotrebom koja može da se vrši sa njom. On bi nam, besumnje, odgovorio da je ova zloupotreba neodvojiva od kulture, ali mi ćemo ga zamoliti da ispita ne dugujemo li uopšte većinu zla koja on pripisuje naukama i umetnostima sasvim različitim uzrocima, čije bi nam nabrajanje ovde bilo dugačko i delikatno.“22 Kao što vidimo, D’Alamber smatra da nije od presudnog značaja uzimati u obzir zloupotrebu kulture, a samim tim i obrazovanja. Njegovi stavovi se prilično razlikuju od Rusoovih, i on tvrdi da

\footnotetext{
${ }^{20}$ Kenet Wain, On Rousseau, University of Malta, Malta, 2011, str. 1.

${ }^{21}$ Dalamber, Žan le Ron, Uvodna rasprava u Enciklopediju, str. 61.

${ }^{22}$ Isto, str. 61, 62.
} 
„moda“ zapravo ne predstavlja preveliku opasnost za čovečanstvo. Uprkos tome što bi se zbog ovako shvaćenog obrazovanja povećao i broj lažnih naučnika i umetnika, D'Alamber smatra da je to možda i jedini razlog što društvo nije palo u varvarstvo, odnosno potpuno odustalo od ideje da je obrazovanje važno. ${ }^{23}$ Sa druge strane, za Rusoa je to bilo presudno pitanje u kontekstu promišljanja obrazovanja.

\section{RUSOOVA KRITIKA OBRAZOVANJA RADI MODE}

Svestan toga koliko se učenost ceni u društvu kome pripada, ŽanŽak Ruso nam takođe ukazuje na činjenicu da nemaju svi jasnu predstavu o tome zbog čega je ona toliko važna. Nema sumnje da se Ruso divio civilizacijskim dostignućima na polju otkrivanja sveta u kome živimo, kao što i sam kaže: „Veličanstven i lep prizor nudi nam se dok posmatramo čoveka kako sopstvenim naporima izranja iz ništavila; kako svetlošću sopstvenog razuma rasteruje tminu kojom ga je priroda bila obavila; kako se uzdiže iznad samog sebe i duhom uzleće sve do nebeskih predela; kako džinovskim koracima, poput sunca, prelazi ogromno prostranstvo svemira; i, što je veličanstvenije i teže, ponire u sebe da bi proučio čoveka i upoznao njegovu prirodu, njegove dužnosti i njegovu svrhu. " ${ }^{24}$ Ako uzmemo u obzir čitavu ljudsku istoriju, čovek je kroz vreme otkrivao sve više, pronalazio objašnjenja za mnoge stvari koje su mu bile nepoznate. Međutim, ako smo zaista toliko mnogo postigli na polju našeg znanja, zar to ne bi trebalo da nam pomogne da živimo sve bolje i bolje u odnosu na naše prethodnike?

Ruso smatra da bi se na osnovu posmatranja društva u kom živi moglo zaključiti nešto sasvim suprotno, a to je da obnova nauka i umetnosti ne samo da nije pomogla ljudima da budu bolji, već je doprinela tome da vremenom budu sve gori: ,...sudbina našeg morala i čestitosti zavisi od napretka nauka i umetnosti. Kako se njihova svetlost uzdizala na našem obzorju, tako je vrlina bežala, $i$ ista je pojava bila uočena u svim vremenima

\footnotetext{
${ }^{23}$ Isto, str. 61.

${ }^{24}$ Ruso, Žan-Žak, ,Rasprava o naukama i umetnostima”, u: Društveni ugovor, Filip Višnjić, Beograd, 1993, str. 189.
} 
i na svim mestima. “25 Kao dokaz ove tvrdnje, Ruso će pružiti opise društva koje se toliko diči svojim uspesima i dostignućima, a zapravo krije mnogo ozbiljnije probleme: ,...kad bi stanovnik neke udaljene zemlje pokušao da o evropskom moralu prosuđuje na osnovu stanja nauka kod nas, savršenstva naših umetnosti, uljuđenosti naših pozorišta, ljubaznosti naših manira, milozvučnosti naših govora, našeg neprestanog pokazivanja blagonaklonosti i onog bučnog mnoštva ljudi svih uzrasta i društvenih položaja, koji kao da se od rane zore do večeri utrkuju da jedni drugima čine usluge, taj bi stranac, ponavljam, o našem moralu stekao utisak potpuno suprotan pravom stanju stvari." ${ }^{26}$ Ovde vidimo Rusoovu snažnu osudu društvenog licemerja i skrivanja iza lažne učtivosti i učenosti.

Posmatrajući iz te perspektive, nije neobično postaviti sledeća pitanja: ako nam napredak u naukama i umetnostima nije doneo ništa korisno i dobro, da li to znači da je bolje da ih nikada nismo ni imali? Da li bismo bili srećniji i spokojniji da smo ostali da živimo u neznanju? Čini se kao da Ruso ovim zaključivanjima želi da sprovede misaoni eksperiment sa namerom da preispita da li su nauke i umetnosti zaista zaslužne za pomenuto izopačenje društva: „Eto kako su luksuz, raspuštenost i ropstvo u svim vremenima bili kazna za ohole napore koje smo činili da bismo izašli iz srećnog neznanja u kojem nas je ostavila večna mudrost... Narodi, shvatite već jednom da je priroda htela da nas poštedi nauke, kao što majka otima iz ruke deteta opasno oružje; da su sve tajne koje vam skriva zapravo zla od kojih vas štiti, i da teškoća sa kojom učite nije njeno najmanje dobročinstvo. Ljudi su pokvareni, a bili bi još gori da su imali tu nesreću da se rode učeni.“27 Podsetimo na to da smo kod D'Alambera imali sličnu metaforu sa detetom, koje simbolizuje čoveka koji još uvek nije spreman da u ruke uzme opasno oružje, odnosno da spozna istinu do kraja. Ruso se pita da li je čovek uzeo preveliki zalogaj onda kada je pomislio da je sposoban za to da jednoga dana barata tim opasnim oružjem. Moglo bi se zaključiti da stvarnost u kojoj živi svedoči o tome da učenost čini ljude još pokvarenijima nego što jesu. Međutim, pitanje je zapravo zašto su svi ti brojni učeni ljudi dozvolili da

\footnotetext{
25 Isto, str. 192.

${ }^{26}$ Isto, str. 191.

${ }^{27}$ Ruso, Žan-Žak, ,Rasprava o naukama i umetnostima”, str. 196.
} 
situacija u društvu bude toliko loša? Ruso postavlja pitanje: ,...da li kod obrazovanog sveta ima više vrlina no mana $i$ da li nisu njihovi poroci sudbonosniji no što su im vrline blagodetne, i da li je napredak u znanju dovoljna naknada za zla koja jedni drugima čine dok govore o dobru kojim bi trebalo uzajamno da se obasipaju;...“28

Ruso kao da želi da svojim stavovima isprovocira sve one koji sebe smatraju intelektualcima, kao što i sam kaže: „Kako su ovakva zapažanja ponižavajuća za čovečanstvo! Koliko naša oholost mora da trpi zbog njih! Zaboga! Zar je čestitost kći neznanja? Zar su nauka i vrlina nespojive? Kakve sve posledice proističu iz ovih predrasuda? Ali, da bismo pomirili ove prividne protivrečnosti, potrebno je samo da izbliza taštinu i ništavilo ovih oholih titula koje nas zasenjuju..." ${ }^{29}$ Kao što vidimo, Ruso govori o prividnim protivrečnostima u kojima su se našle vrlina i znanje, jer on zapravo želi da ispita zbog čega one nisu u saglasju. Smatramo da Ruso nije imao nameru da odbaci nauke i umetnosti, već samo da preispita njihov smisao za društvo. Svaki naučnik, umetnik i filozof je pre svega član društva, i samim tim je (svako na svoj način) odgovoran za to društvo. Ruso smatra da su ljudi njegovog doba zaboravili na tu činjenicu: „Imamo fizičare, geometre, hemičare, astronome, pesnike, muzičare, slikare, ali građana više nemamo; a ako su nam neki još i ostali, raštrkani po našim napuštenim selima, oni tu propadaju siromašni i prezreni.“30

Ruso je bio veliki protivnik lažne obrazovanosti, odnosno onih ljudi koji su težili tome da budu u toku sa modnim trendovima. Čitavo delo Rasprava o naukama i umetnostima, odiše kritikom takvih osobina. Već na samom početku dela Ruso kaže: „U svim vremenima ima ljudi koji su kao stvoreni da se potčinjavaju mnjenjima svog veka, svoje zemlje i svog društva. Sad se prave ateisti i filozofi oni koji bi, sa istom pameću, u vremenu Lige bili fanatici.“31 Kritikovao je sve one mislioce, naučnike i umetnike koji su se trudili da se dodvore ukusu publike, težeći raznim priznanjima i nagradama, umesto da teže ka tome da njihov rad ima istinsku

\footnotetext{
${ }^{28}$ Ruso, Žan-Žak, ,O poreklu i osnovama nejednakosti među ljudima ”, u: Društveni ugovor, Filip Višnjić, Beograd, 1993, str. 153.

${ }^{29}$ Ruso, Žan-Žak, , Rasprava o naukama i umetnostima”, str. 196.

${ }^{30}$ Isto, str. 202.

${ }^{31}$ Isto, str. 188.
} 
vrednost i korist za društvo. Čovek koji izgubi sebe dodvoravajući se drugima, za Rusoa se ne ponaša prirodno, već izveštačeno: ,...i svi duhovi izgledaju kao da su izišli iz istog kalupa: učtivost stalno nešto nalaže a uljudnost zapoveda; stalno se priklanjamo pravilima ponašanja, a nikad sopstvenoj prirodi. Ne usuđujemo se više da se pokažemo onakvima kakvi jesmo..." ${ }^{\text {32 }}$ Ljudi su postali izveštačeni, a takvo je postalo i njihovo obrazovanje.

\section{RUSOOV KONCEPT PRIRODNOG VASPITANJA I OBRAZOVANJA}

Videli smo kako su enciklopedisti smatrali da se problem nalazi u nedostatku obrazovanja, dok Ruso vidi još veći problem u nečemu što smo mi nazvali izveštačenim obrazovanjem. Ruso nam govori: „Na sve strane vidim ogromne zavode u kojima se uz velike troškove podiže omladina, i tu se uči svačemu, osim dužnostima. Vaša deca ne znaju sopstveni jezik, ali će zato govoriti druge jezike koji se nigde ne koriste; umeće da pišu stihove koje će sama jedva razumeti; iako nisu sposobna da razlikuju grešku od istine, naučiće se veštini da ih drugima učine nejasnim služeći se pri tom prividno ispravnim argumentima..." ${ }^{33}$ Uočavamo da je Rusou veoma važno da obrazovanje koje nudimo detetu ima jasan cilj i smisao, kako se ono ne bi pretvorilo u uzaludno učenje onoga što mu neće biti ni od kakve koristi. Smatrao je da bi bilo korisnije pustiti dete da samo uživa u igri kako bi mu se razvilo telo, nego ga primoravati da uči ono što će svakako brzo zaboraviti. ${ }^{34}$

Zbog toga, potrebno je iz korena promeniti odnos spram obrazovanja. Društvo je očigledno grešilo, čak i učitelji, na kojima je bila najveća odgovornost, nisu uspešno obavljali svoj posao, pa je zato Rusoova kritika usmerena i na njihov rad. Problem nastaje onda kada učitelj želi da opravda svoj rad time što će zahtevati od svog učenika da u svakom trenutku demonstrira ono što je naučio: „Znanje, što mu ga on daje, lako će se pokazati, kad kod se hoće; malo mu je stalo do toga da li je korisno ono

\footnotetext{
${ }^{32}$ Isto, str. 190, 191.

${ }^{33}$ Isto, str. 201.

34 Isto.
} 
čemu ga uči, ako se samo lako može primeniti. Bez izbora i bez razlike, on gomila stotinu gluposti u njegovo pamćenje. Kad se radi o ispitu deteta, pozovemo ga da izloži svoju robu; ono je izloži, i mi smo zadovoljni...“35 Učitelj ne bi smeo da gubi iz vida svrhu svog rada s učenikom, koja se ne ogleda u impresioniranju roditelja ili bilo koga drugog, već u njegovom naporu da istinski nečemu nauči svog đaka.

Čitav svoj život, Ruso je duboko osećao nelagodu zbog pomenutog licemerja društva u kom je živeo, i zato mu je često prijala samoća. Mnogi njegovi savremenici, uključujući i njegove bliske prijatelje (kao što je to bio i Didro), tumačili su njegovo osamljivanje kao neku vrstu mržnje prema ljudima. ${ }^{36}$ Međutim, Ruso nikada nije gubio nadu u mogućnost promene na bolje, kako pojedinaca, tako i celokupnog društva. Upravo na takav način mi ćemo tumačiti njegovo delo Emil ili o vaspitanju, u kome Ruso iznosi svoje ideje prirodnog vaspitanja i obrazovanja deteta.

Emil je zamišljeni dečak koji ima jednog vaspitača od rođenja, pa sve do odraslog doba. Cilj je da se pokuša sa vaspitanjem i obrazovanjem deteta koje će biti izolovano od negativnih uticaja društva, kako bi to dete imalo mogućnost da izraste $\mathrm{u}$ čoveka koji neće biti iskvaren svim onim lošim navikama i lažnim vrednostima civilizacije. ${ }^{37}$

Kao što primećuje Kasirer (Cassirer Ernst), Ruso je bio vrlo specifična ličnost, zbog čega je morao da se izoluje od društva kako bi doprinosio tom društvu. ${ }^{38}$ Isti princip je i sa Emilom, ideja je da on bude obrazovan van društva, ali sa ciljem da se u to društvo i vrati. Ruso je, poučen ličnim iskustvom, smislio nov način za vaspitanje i obrazovanje: „U rđavoj okolini, kompromitovan družbom s nedostojnim ljudima, Ruso je imao svesti o svemu, što je u prljavštinama svoga života izgubio od dostojanstva i duševne plemenitosti; zato, da bismo vaspitali čoveka u časti i

\footnotetext{
${ }^{35}$ Ruso, Žan - Žak, Emil ili o vaspitanju, Znanje, Beograd, 1950, str. 197.

${ }^{36}$ Cassirer, Ernst, Rousseau, Kant and Goethe: two essays, Harper and Row, New York, 1963, str. 8.

${ }^{37}$ Deržavin, Konstantin Nikolajevič, Ruso i rusoizam, Kultura, Beograd, 1947, str. 36.

${ }^{38}$ Cassirer, Ernst, Rousseau, Kant and Goethe: two essays, str. 9.
} 
vrlini, izdvojimo sve spoljašnje okolnosti, koje ga mogu uprljati i pokvariti. Emil će živeti sam, daleko od ljudi.“"39

Ruso iznosi tezu da društvo čini čoveka slabijim nego što on uistinu jeste. ${ }^{40}$ Ovo razmišljanje nam je veoma važno u kontekstu promišljanja vaspitanja i obrazovanja. Problemi počinju već u samom detinjstvu, to jest u odnosu koji roditelji imaju sa svojom decom. Umesto da uče svoju decu osamostaljivanju, roditelji bi želeli da njihova deca što duže zavise od njih, kako bi im bila bliskija. ${ }^{41}$ Međutim, to nikako ne doprinosi razvoju detetovih sposobnosti i spremnosti da se suočava sa različitim životnim problemima. Zbog toga, Ruso se protivi običaju roditelja da preterano štite svoje dete. Dete mora od početka da se suočava sa posledicama svog ponašanja: „Ako razbije posuđe kojim se služi, nemojte žuriti da mu nabavite drugo; dajte mu da oseti štetne posledice nemanja. Ako razbije prozore u svojoj sobi, pustite da mu duva vetar i dan i noć ne brinući se hoće li dobiti kijavicu; jer je bolje da dobije kijavicu, nego da ostane budala." ${ }^{\text {(42 }}$ Ovakav pristup mogao bi se tumačiti kao preterano grub i nedelotvoran, s obzirom na to da različita deca drugačije reaguju na iste mere vaspitanja. Međutim, ono što je nama $u$ navedenim primerima važno jeste ideja učenja na osnovu ličnog iskustva.

Ruso smatra da suština nije u tome da deca zapamte što više informacija koje će kasnije znati da ponove kada god se to od njih očekuje, već da se ona uče razumevanju i povezivanju pojmova: „Šta koristi upisati u njihovu glavu čitav katalog znakova za koje oni ne vezuju nikakvu predstavu? ${ }^{\text {“43 }}$ Zbog toga je vrlo važno da vodimo računa o tome kakav sadržaj su deca spremna da uče u određenom životnom dobu: ,,...ako priroda daje detinjem mozgu tu elastičnost koja ga osposobljava da prima sve vrste utisaka, ona nema namere da se u nj urežu imena kraljeva, datumi, nazivi iz heraldike, sferike, geografije, i sve one reči koje nemaju nikakva smisla za njegovo doba..." ${ }^{64}$

39 Kompere, Gabriel, Žan-Žak Ruso i prirodno vaspitanje, Nova štamparija „Davidovićc", Beograd, 1911, str. 16.

${ }^{40}$ Ruso, Žan-Žak, Emil ili o vaspitanju, str. 78.

${ }^{41}$ Isto.

${ }^{42}$ Isto, str. 102.

${ }^{43}$ Isto, str. 119.

${ }^{44}$ Ruso, Žan-Žak, Emil ili o vaspitanju, str. 120. 
Ruso se zalagao za ideju pažljivog praćenja razvoja deteta od samog početka, zato bi bilo idealno da dete ima jednog učitelja koji će ga dobro poznavati. Učitelj bi morao da proceni kada je dete spremno da usvaja određena znanja, u zavisnosti od njegove intelektualne zrelosti. ${ }^{45}$ Cilj nije da primoravamo dete na pamćenje što većeg broja informacija, već je cilj probuditi u njemu želju da i samo istražuje svet, samim tim će imati svest o tome zbog čega su mu sva ta znanja korisna. Učitelj je tu da prati razvoj deteta, da ga upoznaje sa svetom oko njega i da ga neprestano podstiče njegovu radoznalost $i$ istraživački duh. Potrebno je da dete što više uči iz iskustva, jer će tako lakše usvojiti i povezivati znanja: „Moramo nastojati da govorimo delom, koliko je god moguće, a rečima da govorimo samo ono što nije moguće izvesti pred njim. ${ }^{\text {" }} 6$ Kao što smo videli, Ruso je smatrao da je to model obrazovanja koji nedostaje društvu, i tek kada se ovakav način vaspitanja i obrazovanja primeni na decu, možemo očekivati da ona porastu u samostalne ljude, sposobne da misle i da se uspešno suočavaju sa svim životnim preprekama.

\section{ZAKLJUČAK}

Ovim istraživanjem želeli smo da utvrdimo da li je Ruso, koji je nesumnjivo delovao u okviru prosvetiteljskog projekta, a opet izrazio sumnju u vrednost nauka i umetnosti za razvoj društva, ipak ostao dosledan svojim prosvetiteljskim idejama obrazovanja. Pokazali smo da njegovu sumnju u pomenute ideje ne treba shvatiti kao odstupanje od njih, već kao želju da se ponovno preispita da li je društvo zaista spremno da ih prihvati i razume na pravi način. Ruso je smatrao da bi svi prosvetiteljski napori i zalaganja za ostvarenje boljeg društvenog stanja bili uzaludni ako bi se njihove ideje shvatile pogrešno. Obrazovanje shvaćeno kao još jedan od brojnih modnih trendova, ne bi dovelo do ostvarenja ciljeva kojima su stremili prosvetitelji. Videli smo da se Rusoova kritika nauka i umetnosti zapravo odnosi na preispitivanje njihovog značaja za društvo. Ruso nema ništa protiv naučnika i umetnika koji imaju za cilj da svojim radom

\footnotetext{
45 Isto, str. 203.

${ }^{46}$ Isto, str. 227.
} 
doprinesu boljitku društva, već on kritikuje one koji podilaze modnim trendovima i neprestano teže nagradama i priznanjima, ne pitajući se o svrsi i koristi njihovog rada.

Pokazali smo da Ruso nikada nije odustajao od vere u mogućnost da se društvo promeni na bolje. Prosvetitelji su govorili o neophodnosti emancipacije ljudskog uma od svih autoriteta, koju je moguće postići sticanjem što većeg znanja, odnosno širenjem svesti o značaju obrazovanja. Videli smo da se Ruso ne protivi ovim idejama, već da poziva na promene unutar samog društva, odnosno načina na koji su se do sada obrazovala i vaspitavala deca. Ruso je smatrao da je stari pristup potrebno zameniti novim, a koji on naziva prirodnim obrazovanjem. Svoju ideju o prirodnom vaspitanju i obrazovanju Ruso je pokušao da sprovede na svom imaginarnom učeniku Emilu. Pokušao je da na konkretnom primeru vaspitanja Emila pokaže metode kojm bi se deca podsticala na učenje iz iskustva, negovanjem njihove prirodne radoznalosti i želje za znanjem. Upravo na taj način, deca lakše postaju svesna korisnosti i vrednosti znanja koje usvajaju. Dakle, decu bi trebalo podučavati naukama i umetnostima, ali drugačijim metodama nego što se to do tada činilo. Videli smo da je Ruso bio protivnik učenja napamet i gomilanja informacija koje se lako zaborave, zbog čega se zalagao za učenje iz iskustva, buđenje radoznalosti $\mathrm{i}$ istraživačkog duha kod dece.

Ruso je verovao da je društveni napredak moguć jedino ako se društvo sastoji iz slobodnih i sposobnih pojedinca, kao što je Emil. Smatrao je da je pronašao odgovarajući način vaspitanja i obrazovanja dece koja će jednoga dana izrasti u takve ljude. Neki mislioci, kao što je Deržavin (Konstantin Nikolajevič Deržavin), tvrde da je Ruso bio svestan utopičnosti te ideje, ali da ipak nije odustajao od vere u mogućnost poboljšanja stanja u kome se tada nalazilo duštvo: „Pa ipak, on se koristi tom utopičnošću, razrađujući program - maksimum svog pedagoškog ideala s tim da sama slika toga ideala bude najefikasnije sredstvo propagande protiv nakaznosti postojećih sistema vaspitanja i postojećih nastavnih postupaka،“47 Upravo zbog nezadovoljstva obrazovanjem kakvo se do sada praktikovalo, Ruso je namerno izolovao svog vaspitanika, kako bi ga zaštitio od negativnih uticaja

${ }^{47}$ Deržavin, Konstantin Nikolajevič, Ruso i rusoizam, str. 36. 
društva. Međutim, to nikako ne znači da je Ruso zagovarao nekakvo bekstvo iz društva: „Emil nije stvoren za to da večno vodi samostalan život. Kao član društva on ima da ispunjava dužnosti prema njemu. Stvoren da živi s ljudima, on mora da ih pozna." ${ }^{\text {"48 }}$ Kao što vidimo, Ruso je imao jasne namere za svoga Emila, a to su da se on vrati u društvo i živi u zajednici sa drugima. Njegov prethodni način života i vaspitanja bio je, između ostalog, priprema za suočavaje sa ljudima. Ruso je verovao da će ovako odgajano dete biti sposobno da se izbori sa svim preprekama u životu, da ne dopusti da ga zloba i licemerje drugih pokolebaju i iskvare. Kao što možemo uočiti, Ruso nigde ne govori o obrazovanju odraslih ljudi, već je njegov fokus usmeren isključivo na decu. Jedno od mogućih objašnjenja jeste ideja da je Ruso čitav svoj rad usmeravao spram razmišljanja o budućnosti, o generacijama koje tek dolaze, umesto o svojim savremenicima. ${ }^{49}$

Ovo istraživanje imalo je za cilj da pokaže da Rusoovo razumevanje obrazovanja ne može biti u potpunosti shvaćeno ako se ono kritički ne suoči sa prosvetiteljskim idejama. Iako je napetost između prosvetiteljskog i Rusoovog rada očigledna, ciljevi su im identični, a to je širenje obrazovanja u svrhu stvaranja boljeg društva.

\section{LITERATURA}

Cassirer, Ernst, Rousseau, Kant and Goethe: two essays, Harper and Row, New York, 1963.

Dalamber, Žan le Ron, Uvodna rasprava u Enciklopediju, Kultura, Beorad, 1955.

Deržavin, Konstantin Nikolajevič, Ruso i rusoizam, Kultura, Beograd, 1947.

Hegel, Georg Vilhelm Fridrih, Istorija filozofije III, Bigz, Beograd, 1975.

Kenet Wain, On Rousseau, University of Malta, Malta, 2011.

Kompere, Gabriel, Žan-Žak Ruso $i$ prirodno vaspitanje, Nova štamparija „Davidovićc, Beograd, 1911.

Krstić, Predrag, Kritički pojmovnik civilnog društva I, Grupa 484, Beograd, 2003.

Russel, Bertrand, Mudrost zapada, Mladost, Zagreb, 1959.

Ruso, Žan-Žak, „Rasprava o naukama i umetnostima”, u: Društveni ugovor, Filip Višnjić, Beograd, 1993.

\footnotetext{
${ }^{48}$ Isto, str. 451.

${ }^{49}$ Kompere, Gabriel, Žan-Žak Ruso i prirodno vaspitanje, str. 7.
} 
Ruso, Žan-Žak, „O poreklu i osnovama nejednakosti među ljudima”, u: Društveni ugovor, Filip Višnjić, Beograd, 1993

Ruso, Žan-Žak, Emil ili o vaspitanju, Znanje, Beograd, 1950.

Volter, „Hrišćanski razgovor ili obezbjeđivanje od Enciklopedije“, u: $U$ ime savjesti i razuma, Svjetlost, Sarajevo, 1960. 


\author{
KRISTINA TODOROVIĆ \\ University of Novi Sad, Faculty of Philosophy
}

\title{
THE MEANING OF EDUCATION IN ROUSSEAU'S WORKS
}

\begin{abstract}
In this research, the author tries to demonstrate that Rousseau's understanding of education largely coincides with the Enlightenment ideas of the 18th century. Rousseau, together with other Encyclopedists, advocated the idea of emancipation of the mind from authority and spreading of knowledge from various fields of science, philosophy, and also knowledge of various crafts. They believed that progress in knowledge would also contribute to the progress of society. However, Rousseau dared to doubt these ideas, which is why he will be unfairly accused of alienation from these ideas. The author aims to demonstrate that Rousseau's alienation is only apparent and that his notion of natural upbringing and education get along with the Enlightenment ideas. To prove these claims, the author will use the method of analysis and comparison of Rousseau's texts with the texts of his contemporaries. This research aims to present a different interpretation of Rousseau's ideas of education and upbringing, concerning how his contemporaries understood them.
\end{abstract}

Keywords: Rousseau, philosophers of the Enlightenment, criticism, education, natural education 
